\title{
A constitucionalidade do
} poder normativo das agências

reguladoras na ótica do redimensionamento do princípio da legalidade*

The constitutionality of the normative power of the regulatory agencies in the optics of the resizing of the principle of legality

\author{
Jackson Tavares da Silva de Medeiros** \\ Rocco Antonio Rangel Rosso Nelson ***
}

* Artigo recebido em 5 de março de 2012 e aprovado em 13 de agosto de 2012. DOI: http:// dx.doi.org/10.12660/rda.v271.2016.60763.

* Faculdade de Ciências, Cultura e Extensão do Rio Grande do Norte, Natal, Rio Grande do Norte, Brasil. E-mail: jackamedeiros@hotmail.com. Bacharel em direito. Especialista em direito constitucional pela Universidade Federal do Rio Grande do Norte - UFRN. Servidor público do estado do Rio Grande do Norte.

*** Instituto Federal do Rio Grande do Norte - IFRN, João Câmara, Brasil. E-mail: rocconelson@ hotmail.com. Especialista em Ministério Público e direito, cidadania pela Escola Superior do Ministério Público do Rio Grande do Norte. Especialista em direito penal e criminologia pela Universidade Potiguar. Mestre em Direito Constitucional pela UFRN. Ex-professor do curso de direito e de outros cursos do Centro Universitário FACEX. Professor de direito do Instituto Federal do Rio Grande do Norte - IFRN, campus João Câmara. 


\section{RESUMO}

O presente artigo tem por escopo analisar a constitucionalidade do poder normativo das agências reguladoras no Estado brasileiro. Para tanto, será trilhado o caminho da evolução do Estado, passando pelo liberalismo e pelo Welfare State para se chegar ao Estado regulador. Ademais, buscarse-á desmistificar a tentativa de "petrificação" doutrinária de conceitos que se tornaram incompatíveis com as realidades que se insurgiram via complexificação das relações sociais. É o que se pretende ao identificar a necessidade do redimensionamento do princípio da legalidade, que se tornou obsoleto quando pregado exclusivamente nos termos do mundo fechado do formalismo voltado exclusivamente para produção normativa pelo Legislativo, já que não mais atende, dessa forma, às requisições de uma sociedade cada vez mais complexa, dinâmica e técnica. O mesmo seja dito para o princípio da tripartição de poderes que pari passu caminha (ou deve caminhar) para uma maior flexibilização de sua aplicação para fins de satisfação do interesse coletivo e do bem-estar social. Nessa perspectiva, imprescindível se faz estudar o tema em elo com o constitucionalismo, situando o Estado como constitucional democrático de direito, regido por uma constituição que prega e assegura valores e direitos fundamentais, regendo a forma de atuação do Estado na busca pelo bem comum e servindo de parâmetro imprescindível para a flexibilização hermenêutica e produtiva das normas regras e das normas princípios. Com o fito de dar concretização e instrumentalizar os ditames constitucionais, afere-se que o poder normativo das agências reguladoras é um dos mecanismos para atingir tal desiderato, onde o princípio da legalidade da tripartição dos poderes é redimensionado numa ótica neoconstitucionalista.

\section{PALAVRAS-CHAVE}

Agências reguladoras - poder normativo - constitucionalidade princípio da legalidade

\section{SUMMARY}

This article has scope for examining the constitutionality of the normative power of the regulatory agencies in the Brazilian State. Par is trodden the path of evolution of the State, passing through Liberalism Welfare State and to reach the State regulator. In addition, seek will demystify the attempt 
"petrification" doctrinal concepts that have become incompatible with the realities that rose up via complicated social relations. It is the intention to identify the need for resizing of the principle of legality, which became obsolete when nailed exclusively under the closed world of formalism again exclusively for normative production by legislative, since no longer serves in this way, on a requisition society increasingly complex, dynamic and technique. The same is said for the principle of tripartite partition of pari passu powers that walks (or must walk) for greater relaxation of its application for satisfaction of collective interest and social welfare. In this perspective, vital if makes studying the topic link to constitutionalism, the democratic constitutional State, governed by a Constitution that preaches and ensures values and fundamental rights, conducting a form of State action in the quest for the common good and serve as crucial for the relaxation parameter hermeneutics and productive of the standards rules and standards principles. With a view to prepare them to implement and gauges constitutional dictates that the legislative powers of regulatory agencies are one of the mechanisms to achieve this purpose, where the principle of legality of the tripartition of powers are resized in a perspective of a new constitutional right.

\section{KEYWORDS}

regulatory agencies - normative power - constitutionality - principle of legality

\section{Considerações iniciais}

No plano de análise do poder normativo das agências reguladoras, há exigência de um estudo que situe a temática no contexto da evolução do Estado e da sociedade, com o olhar atento para o aspecto socioeconômico e jurídico, bem como para a quebra de paradigmas e a reformulação conceitual que permitam abandonar os anacronismos que obstam a consecução do bem comum e a realização dos direitos fundamentais. É nessa perspectiva que recai a proposta do presente ensaio.

Bem se sabe, pois assim relata a história, que ao longo dos séculos XVIII e XIX foram implantados os ideais do regime liberal. Em razão disso, o Estado passou a desempenhar um papel não intervencionista, de forma que a economia se organizaria por forças próprias e a liberdade individual 
representaria a ideia de que o indivíduo é capaz de produzir suas próprias riquezas. Cabia ao Estado apenas assegurar a liberdade dos indivíduos.

Percebeu-se, entretanto, a insuficiência dos ideários do liberalismo para a consecução dos fins sociais. Dessa forma, uma nova exigência emerge, qual seja: a intervenção do Estado na economia e nas relações sociais. Era a proposta intervencionista do Estado de bem-estar social ou Welfare State, segundo a qual o Estado deveria atuar como empresário, por meio de entidades da administração pública indireta, bem como criar normas, principalmente constitucionais, que assegurassem uma política econômica pautada em justiça social e que atendesse aos fins da democracia.

A elevada oneração das prestações sociais a que se incumbiu o Estado de cumpri-las passou com o tempo a coabitar com a falta de recursos estatais para tais fins, resultando uma nova crise e a exigência de uma nova forma de atuação do Estado. Em razão disso, há uma redução nos espaços de atuação do Estado na economia, passando doravante a denominar-se Estado regulador sob a ótica do que se intitulou neoliberalismo, ou seja, há uma desestatização em que se promoveu uma abertura à iniciativa privada, flexibilizando o monopólio estatal em diversos pontos estratégicos de atuação, sem que o Estado deixasse de regulá-los, entretanto.

É neste contexto que vai se implantar o modelo regulatório via agências reguladoras. Estas constituem autarquias especiais, que integram a administração pública indireta, sendo dotadas de características peculiares que as põem em lugar de destaque, em razão do seu regime jurídico especial, em face das demais entidades autárquicas.

Entre as características peculiares das agências reguladoras está seu poder normativo, que é objeto-matriz do presente estudo.

Discutir a constitucionalidade desse poder é o que se pretende, com o fim de cintilar o ideário de respaldo constitucional das normas editadas por essas autarquias, por meio de análise acurada do princípio da legalidade e da tripartição de poderes.

Outras peculiaridades também são marcantes, tais como a autonomia administrativa, autonomia financeira e orçamentária, poder para dirimir conflitos, poder fiscalizador e o modo como seus dirigentes ocupam tal posto, bem como a forma de como ocorre a desocupação do mesmo.

Com isso, será possível quebrar paradigmas e fazer reluzir novos caminhos que trilhem rumo à concretização da democracia e da vontade constitucional, abandonando-se os anacronismos doutrinários que representem simplesmente entraves ante a efetivação dos valores da Constituição e à realização democrática. 


\section{Breve análise da evolução do Estado 2.10 Estado liberal}

Como ensina Clève, "Das entranhas do Estado absoluto nasceu o Estado Liberal". ${ }^{1}$ A fim de se libertar das amarras do Estado absoluto - que concentrava nas próprias mãos todo o poder de produção normativa capaz de submeter a sociedade às regras de direito impostas, sem admitir, contudo, limites para o próprio poder ${ }^{2}-$, a burguesia se insurge para implantar o que se chama de Estado liberal. ${ }^{3}$

A partir de então, um novo cenário político, econômico, jurídico e social se anuncia. Eram as faces de um novo modelo de Estado. Um Estado absenteísta por excelência, voltado, exclusivamente, para garantir a liberdade dos indivíduos e não intervir na atividade econômica.

Nessa perspectiva, seja qual fosse a ingerência estatal na esfera dos interesses individuais, era considerada ilegítima, em nítida objeção ao Estado absoluto que tudo podia.

Para García-Pelayo, "El liberalismo se caracteriza por ser una concepción individualista; es decir, una concepción para la cual el individuo y no los grupos constituyen la verdadera esencia; los valores individuales son superiores a los colectivos, y el individuo, en fin, decide su destino y hace la Historia". ${ }^{4}$

Em magistral ensinamento, Barroso, a respeito do Estado liberal, explica que "nele vivia-se a afirmação, ao lado dos direitos de participação política, dos direitos individuais, cujo objeto precípuo era o de traçar uma esfera

1 CLÈVE, Clèmerson Merlin. Atividade legislativa do poder executivo. 2. ed. São Paulo: Revista dos Tribunais, 2000. p. 23.

2 Neste contexto, explica Noberto Bobbio que "é absoluto porque se tornou definitivamente o único poder capaz de produzir o direito, isto é, de produzir normas vinculatórias para os membros da sociedade sobre a qual impera, e, portanto, não conhecendo outros direitos senão o seu próprio, nem podendo conhecer limites jurídicos para o próprio poder. É um poder absoluto no sentido próprio da palavra, isto é, como legibus solutus" (BOBBIO, Norberto. Direito e Estado no pensamento de Emanuel Kant. 2. ed. Tradução de Alfredo Fait. São Paulo: Mandarim, 2000. p. 19).

3 Cf. "[...] liberal pela ideia de liberdade no propósito de limitação do poder político e redução de suas funções perante a sociedade civil e burguês em função de sua identificação, principalmente no século XIX, com os valores e interesses da burguesia, a qual conquista o poder político e econômico" (LEHFELD, Lucas de Souza. Controles das agências reguladoras. São Paulo: Atlas, 2008. p. 51).

4 GARCÍA-PELAYO, Manuel. Derecho constitucional comparado. 4. ed. Madri: Revista de Ocidente, S.A., 1957. p. 143. 
de proteção das pessoas em face do Poder Público. Estes direitos, em sua expressão econômica mais nítida, traduziam-se na liberdade de contrato, na propriedade privada e na livre-iniciativa". ${ }^{5}$

Conforme Justen Filho, "O Estado Liberal do século XIX se peculiarizava por uma concepção omissiva. A função do Estado era a garantia da manutenção das condições de liberdade, para propiciar aos agentes sociais a realização de seus objetivos e finalidades" ${ }^{6}$

A liberdade contratual e a propriedade privada constituíram pilastrasmestras das liberdades jurídicas que constituíam direitos individuais, os quais cabiam ao Estado, apenas, assegurá-los.

Sobre o aspecto econômico, em lição lapidar, ensina Aragão:

Sob o ângulo da atividade econômica privada os principais fundamentos do Estado liberal-burguês eram a propriedade, pela qual se assegurava a titularidade, o gozo e a fruição dos bens, e os contratos, veículos da circulação desses bens. Sobre ambos à Administração Pública não competia impor qualquer restrição, salvo se necessária para que os direitos de outros cidadãos não fossem prejudicados. Acreditava-se que o mercado seria muito mais benéfico para o conjunto da sociedade se agisse livremente, não devendo ser funcionalizado por qualquer finalidade coletiva. ${ }^{7}$ [grifo nosso]

Por sua vez, Carvalho Filho elucida que

No setor econômico, a ideia central residia na liberdade individual, sem interferência do poder estatal. O postulado iluminista era o "laissez faire, laissez passer', pois que "le monde va lui même". Aos indivíduos caberia determinar seus próprios interesses; dever-se-ia conferir-lhe a total liberdade de promover sua própria riqueza; cada um seria juiz de suas próprias conveniências. ${ }^{8}$

5 BARROSO, Luis Roberto. Constituição e ordem econômica e agências reguladoras. Revista Eletrônica de Direito Administrativo Econômico, Salvador, n. 1, fev. 2005. Disponível em: <www. direitodoestado.com.br>. Acesso em: 25 dez. 2011.

6 JUSTEN FILHO, Marçal. O direito das agências reguladoras independentes. São Paulo: Dialéctica, 2002. p. 20.

7 ARAGÃO, Alexandre Santos de. Agências reguladoras e a evolução do direito administrativo econômico. 2. ed. Rio de Janeiro: Forense, 2006. p. 49.

8 CARVALHO FILHO, José dos Santos. Estado mínimo $\times$ Estado máximo: o dilema. Revista Eletrônica sobre a Reforma do Estado, Salvador, n. 12, dez./jan./fev. 2008. Disponível em: <HTTP:// direitodoestado.com.br>. Acesso em: 20 dez. 2011. 
Dessa forma, nota-se que a economia deveria se sujeitar às leis naturais de mercado, sem intervenção do Estado, cabendo aos membros da sociedade, de forma individual e liberal, construir a própria riqueza, o que resultaria em benefícios para toda a sociedade, cuja riqueza dependeria da riqueza dos indivíduos que a incorpora.

Neste contexto, é notório que "[...] o liberalismo foi decisivo para mudanças importantes na conjuntura global, como a adoção das liberdades individuais como verdadeira proteção da esfera de atuação do indivíduo e, no campo econômico, o afastamento da intervenção do Estado na atividade econômica...". ?

Apesar do importante papel do liberalismo, que conseguiu fazer surgir direitos fundamentais à vida privada assegurados normativamente e que permitiu um desenvolvimento civilizatório nunca antes visto, com base na produção de bens e serviços e nas inovações tecnológicas, o afastamento do Estado mostrou-se inadequado, quando da análise dos problemas sociais decorrentes dos ideários do Estado liberal.

É que "essa expansão da atividade econômica ocorrida no século XIX também gerou complicações, como o surgimento de grandes empresas fabris (concentração econômica) e, consequentemente, diversos problemas sociais, como desemprego, exploração excessiva do trabalho, pobreza e concentração populacional" ${ }^{10}$

Viu-se, logo, a necessidade da presença interventiva do Estado como forma de resguardar a harmonia social e o equilíbrio econômico, de vez que o Estado liberal-burguês com o não intervencionismo extremo se mostrou incapaz de solucionar os graves problemas sociais oriundos das práticas liberais, fazendo-se prevalecer, a partir de então, o bem-estar da sociedade perante o individualismo radical do liberalismo. Surgia o Estado de bem-estar social.

\subsection{O Estado de bem-estar social (Welfare State)}

Com o Estado de bem-estar social insurge o alargamento de intervenção estatal para fins de restabelecer o equilíbrio econômico e resguardar

9 Lehfeld, Controles das agências reguladoras, op. cit., p. 52.

10 Ibid., p. 53. 
a harmonia social. A visão coletiva, de bem comum, fazia-se prevalente ante o individualismo extremo do Estado liberal. O Estado agora carregava a incumbência de promover benefícios tanto para a sociedade quanto para o setor econômico.

Conforme explica Lehfeld,

[...] o Estado passou a atuar como empresário, utilizando-se de entidades da Administração Pública indireta, como as empresas estatais e as sociedades de economia mista, para intervir na economia, concorrendo com a iniciativa privada. Por outro lado, também se valeu da criação de normas, especialmente constitucionais, para assegurar os objetivos de uma política econômica que atribui à iniciativa privada a propriedade e a atividade econômica, sem esquecer de regular e incentivar a economia com o objetivo de suprir as deficiências do mercado (para o seu bom funcionamento) e estabelecer mecanismos de concorrência. ${ }^{11}$

Não é só na economia, ressalte-se, que o Estado social passa a intervir: “a ideia de Estado de Bem-Estar envolve o ativismo socioeconômico dos organismos políticos. Isso equivale a reconhecer ao Estado o dever de modelar as relações sociais vigentes na comunidade" ${ }^{12}$

Conforme Barroso,

O Estado assume diretamente alguns papéis econômicos, tanto como condutor do desenvolvimento como outros de cunho distributivista, destinados a atenuar certas distorções do mercado e amparar os contingentes que ficavam à margem do progresso econômico. Novos e importantes conceitos são introduzidos, como os de função social da propriedade e da empresa, assim como se consolidam os chamados direitos sociais, tendo por objeto o emprego, as condições de trabalho e certas garantias aos trabalhadores. ${ }^{13}$

Por meio do intervencionismo estatal, buscava-se amenizar os efeitos dos problemas herdados do Estado liberal decadente. A busca por justiça social e equilíbrio econômico agora abarcaria o ativismo direto do Estado.

11 Ibid., p. 58.

12 Justen Filho, O direito das agências reguladoras independentes, op. cit., p. 20.

13 Barroso, Constituição e ordem econômica e agências reguladoras, op. cit. 
Conforme Justen Filho, "o Estado e o Direito buscam (têm de buscar) a promoção do bem-estar concreto dos cidadãos, a supressão da pobreza e das desigualdades, a promoção da dignidade da pessoa humana. Esses ideais políticos conduziram ao florescimento de ideais de ativismo e intervencionismo estatal" ${ }^{14}$

Todavia, por assumir essa postura intervencionista, garantista do desenvolvimento socioeconômico, o Estado teria que ser prestador de serviços e empresário para poder reduzir os problemas sociais e equilibrar o setor econômico, o que exigia elevada soma de recursos financeiros, em razão da excessiva oneração pelas prestações por ele assumidas.

Em função disso é que ocorre o que a doutrina denomina de "crise fiscal". ${ }^{15}$

Embora se tenha presenciado avanços sociais, nunca antes vistos, tais como, lembra Justen Filho, melhoria nas condições de vida, elevação da expectativa de vida média da população, conforto e inúmeros benefícios democráticos como saneamento, educação e previdência, ${ }^{16}$ isso implicou insuficiência econômico-financeira para que o Estado pudesse cumprir os compromissos assumidos e assegurar futuro desenvolvimento.

Dada essa crise do Estado social, outra forma de atuação estatal, com base em parâmetros políticos e econômicos inovadores, havia de ser buscada. Foi esse o contexto que fez surgir o neoliberalismo que, "ao contrário do modelo estatal anterior, nada promete, mas parece tudo cumprir, com uma mudança do papel do Estado fomentador da atividade econômica, que passa agora a ser regulador". ${ }^{17}$

\subsection{Ostado neoliberal e o perfil regulador}

A noção de neoliberalismo recai numa transmutação da atuação do Estado no setor econômico, deixando de atuar como fomentador para exercer a regulação da atividade econômica.

14 Justen Filho, O direito das agências reguladoras independentes, op. cit., p. 17.

15 "A expressão passou a ser utilizada para indicar a situação de insolvência governamental, inviabilizadora do cumprimento das obrigações assumidas e do desenvolvimento de projetos mais ambiciosos". (Cf. Ibid., p. 19).

16 Ao abordar o assunto, o autor além de trazer à tona esses avanços na condição de vida das pessoas, diz que "o resultado foi extraordinariamente positivo; espantoso, poderia até dizerse." (Justen Filho, O direito das agências reguladoras independentes, op. cit., p. 18).

17 Cf. Lehfeld, Controles das agências reguladoras, op. cit., p. 60. 
Isso decorre da crise do Welfare State, que demonstrou que o Estado por si só não teria recursos financeiros para solver todos os compromissos assumidos com a sociedade para a prestação das necessidades públicas.

Deve-se atentar para o que preleciona Lehfeld:

Percebe-se que o Estado neoliberal, diferentemente do liberalismo, preocupa-se com uma economia de mercado com menor controle do capital. Busca-se uma maior liberdade por parte da iniciativa privada no campo da economia, reduzindo o intervencionismo estatal até então preponderante em razão do chamado Estado do Bem-Estar Social. Na realidade o neoliberalismo conduz a uma modificação do papel do Estado, que deixa de ser fomentador da atividade econômica e passa a ser regulador, preocupando-se de forma direta apenas com relação àquelas atividades essenciais, inerentes à sua criação, como segurança, saúde, habitação, educação (exemplos: previdência social e gratuidade da saúde e educação). Esse é o denominado Estado mínimo (seria melhor Estado diferente, em razão da dificuldade de aplicação dessa política econômica neoliberal na prática....). ${ }^{18}$

É nesta perspectiva que se tem a ampliação da iniciativa privada e a redução do Estado, como forma de reduzir os elevados encargos estatais decorrentes da política do Estado social e de promover com eficiência o atendimento às necessidades públicas. "Se o Estado reduzir sua atuação direta e atribuir aos particulares o poder de levar avante inúmeras atividades, a contrapartida será a regulação" ${ }^{19}$

A ideia de Estado neoliberal, portanto, não permite que se pense um mero repasse da satisfação das necessidades individuais e coletivas para a iniciativa privada, ou seja, simples privatização.

Incumbe ao Estado atuar para assegurar o bem-estar social, de forma mais eficiente, e o equilíbrio econômico, apenas agora de forma indireta, como fiscalizando e regulando o setor privatizado. Percebe-se uma junção dos ideários liberais com os do Welfare State.

Daí Justen Filho lembrar que

Admite-se a redução da dimensão do Estado não porque se repudie o dever de o Estado promover os valores fundamentais (entre os quais

18 Ibid., p. 61.

19 Justen Filho, O direito das agências reguladoras independentes, op. cit., p. 322. 
avulta o princípio da dignidade da pessoa humana). A substituição do Estado pelo agente econômico privado deriva da ideia de que essa opção pode realizar com maior intensidade os princípios fundamentais afirmados desde a Revolução Francesa e que integram o núcleo do conceito de Estado de Bem-Estar. ${ }^{20}$

O plano nacional de desestatização que se implantou no Brasil na década de 1990, flexibilizando o monopólio do Estado em diversas áreas estratégicas, o que se notou nos setores de energia elétrica, petróleo e telecomunicações, é reflexo dessa transformação do papel do Estado, havendo uma forte abertura da atividade econômica à iniciativa privada. ${ }^{21}$

Nesse contexto, a necessidade de regulação é clarividente, pois que "o Estado tem o dever de assegurar que as necessidades individuais e coletivas continuem a ser satisfeitas, depois de produzida a privatização". ${ }^{22}$

É a partir dessa ideia de adoção da concepção regulatória pelos Estados que se consagram as agências reguladoras independentes, ${ }^{23}$ pois é o que se pode concluir "se for reputado que um modelo regulatório de Estado pressupõe a existência de entidades autônomas com perfil de agências". ${ }^{24}$

\section{O redimensionamento do princípio da legalidade 3.1 O princípio da legalidade na ótica da atual tripartição de poderes}

É com a noção liberal oitocentista de separação de poderes que surge o princípio da legalidade. A classe burguesa, diante das medidas que lhe eram impostas pelo rei absolutista, buscou estabelecer um meio pelo qual as normas jurídicas, que eram estabelecidas pelos representantes da burguesia, fossem um ponto de referência do qual deveria decorrer toda medida jurídica, fazendo com que o administrador e o juiz exercessem funções de mera cognição, cabendo a eles somente a execução da lei já posta. ${ }^{25}$

\footnotetext{
Ibid., p. 328.

Cf. Lehfeld, Controles das agências reguladoras, op. cit., p. 64.

Ibid., p. 325.

Cf. Ibid., p. 129.

Ibid., p. 328.

25 Cf. ARAGÃO, Alexandre Santos. Legalidade e regulamentos administrativos no direito contemporâneo. Uma análise doutrinária e jurisprudencial. Revista de Direito Constitucional e Internacional, São Paulo, n. 41, p. 284-310, out./dez. 2002.
} 
Isso porque, com o advento do Estado absoluto, o monarca passou a concentrar em suas mãos todo o poder, sendo soberanamente legitimado em seu agir. A doutrina liberal objetivava a exata limitação do poder real como forma de fazer valer as liberdades individuais e assegurar a não intervenção do Estado na atividade econômica.

Buscava-se então limitar juridicamente o Estado para, por conseguinte, concretizar a liberdade individual e social ante as ingerências estatais. Isso se daria na conjugação de esforços produzidos pelo princípio da legalidade e pelo da tripartição de poderes. "[...] A concepção de separação e limitação recíproca de poderes garante a aplicação concreta do princípio da legalidade" ${ }^{26}$

No seio do liberalismo, portanto, dada a importância da lei para assegurar a esfera intocável da liberdade individual ante as ações do Estado, foi dado ao Poder Legislativo, e por este ser o Poder representante da vontade do povo via produção normativa, um posto de supremacia em relação aos demais Poderes.

Tendo John Locke como precursor, Montesquieu, ${ }^{27}$ a quem o Estado moderno deve a elaboração da teoria da tripartição de poderes, ${ }^{28}$ por preocupação com os limites do poder, formula a ideia pela qual o poder deve ser limitado pelo próprio poder. ${ }^{29}$

Elucida Clève: “[...] Ora, nesse sistema, não é difícil entender que a técnica da separação de poderes, tal como formulada por Montesquieu, funcionava perfeitamente, além de alcançar uma utilidade incontestável", ${ }^{30}$ pois que ressaltava a limitação jurídica do poder estatal em favor da consecução das liberdades individuais.

Para a consecução dos fins almejados pelos teóricos do liberalismo, a lei deveria existir como vontade geral do povo, sendo, portanto, produção normativa monopolizada pelo Poder Legislativo, vez que era o parlamento

26 OLIVEIRA, Rafael Carvalho Rezende. Constitucionalização do direito administrativo. 2. ed. Rio de Janeiro: Lumen Juris, 2010. p. 38.

27 "Sem percorrer a obra de John Locke e Montesquieu, tome-se como verdade que o modelo clássico ou puro de separação de poderes veio do engenho dos dois filósofos..." Cf. PAULA, Daniel Giotti de. Ainda existe separação de poderes? A invasão da política pelo direito no contexto do ativismo judicial e da judicialização da política. In: PAULA, Daniel Giotti de; FELLET, André Luiz Fernandes; NOVELINO, Marcelo (Org.). As novas faces do ativismo judicial. Salvador: Jus Podivm, 2011. p. 274.

28 Cf. CLÈVE, Clèmerson Merlin. Atividade legislativa do Poder Executivo. 2. ed. São Paulo: Revista dos Tribunais, 2000. p. 24.

29 Cf. Oliveira, Constitucionalização do direito administrativo, op. cit., p. 38.

30 Clève, Atividade legislativa do Poder Executivo, op. cit., p. 34. 
quem representava a nação. O Legislativo era o Poder eleito pelo povo, dotando-se, por isso, de superioridade.

Ocorre que a crise do Estado liberal exigiu uma nova forma de atuação do Estado. Conforme Clève,

A crise recorrente do capitalismo, o sufrágio universal, as reivindicações da classe operária, as revoluções socialistas, a passagem da empresa individual para a coletiva e da concorrência para o oligopólio, a emergência da sociedade de massas e a consequente urbanização pela qual passou o mundo, esses dados todos, somados a outros, concluíram por forçar o nascimento de um novo tipo de Estado. ${ }^{31}$

Saía de cena o Estado não intervencionista para entrar o Estado que deveria, por meio de prestações, equilibrar a economia e harmonizar o convívio social, redistribuindo riquezas e buscando implantar os pressupostos da justiça social. É nesse contexto que se alargam as dimensões de atuação do Poder Executivo, corolário do Estado de bem-estar social.

A sociedade se tornou cada vez mais dinâmica e complexa, com interesses mais e mais heterogêneos, mormente com a conquista do sufrágio universal, em contraposição aos interesses homogêneos da burguesia liberal dominante que singularizava seus anseios por meio do voto censitário. ${ }^{32}$

Segundo preleciona Clève:

O vir à tona do Estado Social e da Sociedade técnica dificulta o exercício, pelo parlamento, da função legislativa. Primeiro, porque o Estado social e a sociedade técnica exigem do Legislativo um preparo técnico que não pode ser encontrado num órgão cuja composição não é de especialistas, e sim de mandatários eleitos. Depois, porque o processo legislativo nem sempre pode ser célere. De uma estrutura colegial, formada por um número sempre pequeno de congressistas, não se pode exigir que a tomada de decisão seja tão rápida como a do Executivo. ${ }^{33}$

31 Ibid., p. 41.

32 É neste sentido que ensina Rafael Carvalho Rezende Oliveira, ao aduzir que "[...] a homogeneidade dos interesses a serem protegidos - característica típica do Estado Liberal Burguês, que deveria atender às necessidades de uma classe dominante (a burguesia) e que estabelecia o voto censitário - cede espaço à heterogeneidade dos interesses existentes na sociedade complexa atual." Oliveira, Constitucionalização do direito administrativo, op. cit., p. 40.

33 Clève, Atividade legislativa do Poder Executivo, op. cit., p. 53. 
Não se pode desbordar da lapidar lição de Moncada que trata da seguinte forma:

[...] Avulta a progressiva transferência de poderes legislativos do parlamento, seu lugar tradicional, para os Governos, sempre mais próximos dos interesses parcelares da Sociedade Civil a exigirem um conteúdo da lei que os sirva e, sobretudo, a teleologia da lei, preocupada com questões de produtividade e eficiência, pouco ou nada compatíveis com uma consideração imparcial e distanciada dos interesses a atender, a pedir um conteúdo comprometido mais do que justo. ${ }^{34}$

Tanto que, conforme Dallari, ao se referir à tripartição de poderes,

[...] proposta essa ideia de maneira sistemática no século XVIII, com o fim exclusivo de proteção da liberdade, mais tarde seria desenvolvida e adaptada a novas concepções, pretendendo-se então que a separação dos poderes tivesse também o objetivo de aumentar a eficiência do Estado, pela distribuição de suas atribuições entre outros órgãos especializados. ${ }^{35}$

O que se denota, nessa perspectiva, é uma necessária flexibilização e releitura conceitual, tanto do princípio da separação de poderes quanto do princípio da legalidade. É uma necessidade mesma da complexidade social, que se mostra cada vez mais técnica e exigente.

Isso não significa desprezo pela e abandono da construção doutrinária realizada no curso da história, mas sim um incremento para fins de adequação ao contexto da sociedade atual, que, ao exigir o cumprimento de interesses sociais por parte do Estado, contribui para uma produção normativa cada vez mais intensa, sobrecarregando a própria atuação do Poder Legislativo.

Lúcidas são as palavras de Clève quando afirma:

O jurista não deve ficar indignado com a contemporânea sobrecarga do Legislativo. A sobrecarga será solucionada, seja pela simplificação do processo legislativo, seja pela entrega de parte da função normativa

34 MONCADA, Luís S. Cabral de. Ensaio sobre a lei. Coimbra: Coimbra, 2002. p. 92.

35 DALLARI, Dalmo de Abreu. Elementos de teoria geral do estado. 24. ed. São Paulo: Saraiva, 2003. p. 216. 
a outros órgãos ou instâncias estatais, em particular para o Executivo legitimado pelo voto popular. A sacralização da lei, ocorrida no século XIX, decorreu do fato de apenas o Legislativo representar a vontade da nação. Embora não se possa mensurar até que ponto o Executivo deixa de representar a nação como o Legislativo, o certo é que o conceito de lei, como o comando normativo estatal proveniente do Legislativo e dotado das características de generalidade (abstração e impessoalidade) e permanência, não se compatibiliza com a sociedade técnica. [grifo nosso]

Daí, "a missão atual dos juristas é a de adaptar a ideia de Montesquieu à realidade constitucional do nosso tempo. Nesse sentido, aceita-se aparelhar o Executivo, sim, para que possa, afinal, responder às crescentes e exigentes demandas sociais". ${ }^{36}$

\subsection{Neoconstitucionalismo e o princípio da legalidade}

Com a evolução do constitucionalismo, chegou-se ao que hoje se denomina neoconstitucionalismo. As lutas sociais na busca por direitos fazem surgir ideias que vão marcando a história, em cada espaço e tempo, por conceitos que precisam ser renovados e inovados para que não se perca no tempo a essência da busca humana pela satisfação individual e social. Essa é a cara do constitucionalismo contemporâneo.

Analisando uma nova forma de estudar a constituição, ensina Bonavides:

Com a queda do positivismo e o advento da teoria material da Constituição, o centro de gravidade dos estudos constitucionais, que dantes ficavam na parte organizacional da Lei Magna - separação de poderes e distribuição de competência, enquanto forma jurídica de neutralidade aparente, típica do constitucionalismo do Estado Liberal - se transportou para a parte substantiva, de fundo e conteúdo, que entende com os direitos fundamentais e as garantias processuais da liberdade, sob a égide do Estado Social. ${ }^{37}$

36 Clève, Atividade legislativa do poder executivo, op. cit., p. 44.

37 BONAVIDES, Paulo. Curso de direito constitucional. 23. ed. São Paulo: Malheiros, 2008. p. 599. 
Barroso $^{38}$ explana três marcos para um novo direito constitucional: no marco histórico está, na Europa continental, "o constitucionalismo do pósguerra, especialmente na Alemanha e na Itália". No Brasil, por sua vez, assumiu tal papel "a Constituição de 1988 e o processo de redemocratização que ela ajudou a protagonizar". Quanto ao marco filosófico, o autor diz ser ele o pós-positivismo.

Já o marco teórico, três grandes transformações o constitui, segundo o autor retro, quais sejam: "o reconhecimento de força normativa à Constituição", "a expansão da jurisdição constitucional" e "o desenvolvimento de uma nova dogmática da interpretação constitucional".

É neste contexto que a Constituição passa a protagonizar o ordenamento jurídico, sendo reconhecida como norma jurídica e tendo força capaz de exigir a compatibilidade das demais normas com ela, por meio do controle de constitucionalidade.

Isso desencadeou um processo de constitucionalização do direito.

Uma nova visão de leitura e aplicação do direito, buscando a máxima concretização dos direitos fundamentais, é o que se pretende, ou seja, uma nova hermenêutica não só para as regras, mas também para os princípios, capaz de contribuir com a efetivação de um Estado constitucional democrático de direito.

Não mais se pode imaginar, portanto, pelo menos na concepção de um Estado constitucional democrático de direito, uma construção normativa que se afaste dos mandamentos constitucionais pautados em direitos e garantias fundamentais e na dignidade humana.

O que se percebe, com isso, é a necessidade de acomodação normativa aos ditames constitucionais. Logo, as normas principiológicas, também, estão sujeitas a tal acomodação, e com o princípio da legalidade não pode ser diferente.

Dada essa importância à Constituição, para concretização de sua vontade deslocou-se o protagonismo antes atribuído ao Poder Legislativo para o Poder Judiciário que, ao interpretar e aplicar as normas constitucionais de forma derradeira e vinculativa, exerce a jurisdição constitucional. "De poder quase 'nulo', mera 'boca que pronunciava as palavras da lei', como lhe chamara

38 BARROSO, Luis Roberto. Neoconstitucionalismo e constitucionalização do direito (o triunfo tardio do direito constitucional no Brasil). Revista Eletrônica sobre a Reforma do Estado (Rere), Salvador, n. 9, mar./abr./maio 2007. Disponível em: <HTTP://direitodoestado.com.br/rere. asp>. Acesso em: 22 set. 2011. 
Montesquieu, o Poder Judiciário se viu alçado a uma posição muito mais importante no desenho institucional do Estado contemporâneo" ${ }^{39}$

Conforme aduz Sampaio Júnior,

[...] verificou-se que não só a sociedade mudou, mas o próprio Direito evoluiu para atender a essa mudança social, como deve ser, conduzindo, por conseguinte, a uma necessidade inarredável de que a atividade jurisdicional se amolde à conjuntura atual e para tanto aquela idéia de simples desvelar da vontade abstrata da lei no caso concreto não mais atende aos anseios e não se coaduna com o ideário democrático.

Desta forma é imprescindível que em cada situação específica haja a construção de uma norma jurídica que atenda as necessidades específicas de direito material pleiteado e que ao mesmo tempo estejam em conformidade com os direitos e garantias fundamentais dos cidadãos, tudo para salvaguardar uma efetiva democracia numa visão substancial que defendemos. ${ }^{40}$

Dessa forma, mostra-se imperioso redimensionar o olhar voltado para o princípio da legalidade, pois tanto ele como o da tripartição de poderes são exigências, antes de tudo, da concretização de uma vontade constitucional, cuja base recai nos direitos fundamentais e na dignidade humana.

Não se pretendendo, aqui, por óbvio, banalizar a aplicação e o devido respeito aos princípios, mas identificar que a flexibilização dos mesmos constitui exigência do Estado constitucional democrático de direito.

\subsection{A deslegalização ou delegificação}

O sentido da delegificação ${ }^{41}$ recai na atribuição do poder normativo a órgãos ou entidades da administração pública, pelo próprio Poder Legislativo,

39 SARMENTO, Daniel. O neoconstitucionalismo no Brasil: riscos e possibilidades. In: DE PAULA, Daniel Giotti; Fellet, André Luiz Fernandes; NOVELINO, Marcelo (Org.). As novas faces do ativismo judicial. Salvador: JusPodivm, 2011.

40 SAMPAIO JÚNIOR, José Herval. Ativismo judicial: autoritarismo ou cumprimento dos deveres constitucionais? In: De Paula, Fellet e Novelino, As novas faces do ativismo judicial, op. cit.

41 "A deslegalização ou delegificação é mais uma novidade do que propriamente legislativa. Ou seja, antes de a doutrina começar a sistematizá-la, várias de nossas leis e regulamentos a 
mediante lei. Consiste, conforme Moreira Neto, ${ }^{42}$ na "retirada, pelo próprio legislador, de certas matérias, do domínio da lei (domaine da la loi) passando-as as domínio do regulamento (domaine de l'ordonnance)".

A definição de delegificação por García de Enterría e Fernández se faz imprescindível, dado o grau de precisão quando firmam assim: "Llamamos deslegalización a la operación que efectúa una Ley que, sin entrar en la regulación material de un tema, hasta entonces regulado por Ley anterior, abre dicho tema a la disponibilidad de la potestad reglamentaria de la Administración" ${ }^{43}$

Pode-se entender que o fenômeno da delegificação constitui uma exigência da complexidade da sociedade que se apresenta cada vez mais técnica. A necessidade de produção normativa que atenda aos reclamos sociais não está sendo suprida a contento por obra exclusiva do Poder Legislativo, seja pela excessiva demanda normativa, seja pelo despreparo técnico do núcleo parlamentar.

Por outro lado, com o advento do Welfare State, o Estado assumiu um intervencionismo social com o objetivo e dever de cumprir de forma eficaz as tarefas correspondentes ao bem-estar da sociedade. "Na medida em que o poder estatal deve responder, de forma mais eficiente, aos avanços técnicos e científicos, justifica-se a elevação da margem de decisão em favor do Executivo" ${ }^{4}$

Indispensável o magistério de Justen Filho, que ao tratar da evolução da deslegalização, no contexto das fontes normativas no direito italiano, explica:

Através desse instrumento, propicia-se a ampliação dos polos normativos, atribuindo-se competência para produção de normas não apenas ao Governo propriamente dito, mas também a outros sujeitos, inclusive autoridades independentes e sujeitos privados. É resultado de

incorporaram. Na verdade, a deslegalização é um instituto umbilicalmente ligado à atribuição, mormente na seara econômica, de largos poderes normativos a órgãos ou entidades da Administração Pública. É uma consequência, embora não necessária, da atribuição de tais poderes pela lei." Aragão, Agências reguladoras e a evolução do direito administrativo econômico, op. cit., p. 118.

42 Ibid., p.119.

43 ENTERRÍA, Eduardo García; FERNÁNDEZ, Tomás-Ramón. Curso de derecho administrativo. Madri: Civitas, 2002. v. I, p. 275.

44 É o que afirma Andreas J. Krell ser o pensamento de Michael Lothar. In: KRELL, Andreas J. Leis de normas gerais, regulamentação do Poder Executivo e cooperação intergovenamental em tempos de Reforma Federativa. Belo Horizonte: Fórum, 2008. 
inúmeras propostas derivadas da dificuldade ou lentidão da atuação do Parlamento, o que produzia impasses de difícil superação. ${ }^{45}$

A lei de deslegalização, portanto, gera uma degradação na hierarquia normativa da regulação, pois permite que a matéria regulada por lei anteriormente possa ser regulada por meros regulamentos. ${ }^{46}$ "A lei deslegalizadora não chega a determinar o conteúdo material da futura normatização administrativa, limitando-se a estabelecer standards e princípios que deverão ser respeitados na atividade administrativo-normativo" ${ }^{47}$

A delegificação é, portanto, um ato de política legislativa que, dadas as circunstâncias que o ordena, caminha em consonância com os ditames constitucionais e com interesses sociais de uma sociedade que legitima a própria existência do Estado, pois é para atender "as necessidades práticas de uma regulação social ágil e eficiente" ${ }^{48}$ que tal instituto existe.

\section{O poder normativo das agências reguladoras}

\subsection{Agências reguladoras e o seu poder normativo}

Para que melhor se entenda o que vêm a ser agências reguladoras, ${ }^{49}$ Justen Filho propõe, para fins didáticos, a seguinte definição:

45 Justen Filho, O direito das agências reguladoras independentes, op. cit., p. 222.

46 Esta compreensão é permitida, pelo que reza Eduardo Garcia de Enterría: "Uma lei de deslegalização opera como contrarius actus da anterior lei de regulação material, porém, não para inovar diretamente esta regulação, mas para degradar formalmente o grau hierárquico da mesma de modo que, a partir de então, possa vir a ser regulada por simples regulamentos. Deste modo, simples regulamentos poderão inovar e, portanto, revogar leis formais anteriores, operação que, obviamente, não seria possível se não existisse previamente a lei degradadora". (Aragão, Agências reguladoras e a evolução do direito administrativo econômico, op. cit., p. 420).

47 Oliveira, Constitucionalização do direito administrativo, op. cit., p. 71.

48 É de Aragão tais palavras quando ele afirma que "as necessidades práticas de uma regulação social ágil e eficiente (art. 37, caput, CF) imporão o amplo acatamento do instituto da deslegalização, até porque, além das razões de ordem prática, reveste-se de sólidos argumentos teóricos" (Aragão, Agências reguladoras e a evolução do direito administrativo econômico, op. cit., p. 422).

49 Aragão, em uma tentativa conceitual para as agências reguladoras independentes brasileiras, aduz que são "autarquias de regime especial, dotadas de considerável autonomia frente à Administração centralizada, incumbidas do exercício de funções regulatórias [...] e dirigidas por colegiado cujos membros são nomeados por prazo determinado pelo Presidente da República, após previa aprovação pelo Senado Federal, vedada a exoneração ad nutum." (Ibid., p. 275). 
É uma autarquia especial, criada por lei para a intervenção estatal no domínio econômico, dotada de competência para regulação de setor específico, inclusive com poderes de natureza regulamentar e para arbitramento de conflitos entre particulares, e sujeita a regime jurídico que assegure sua autonomia em face da Administração direta. ${ }^{50}$

A necessidade de o Estado interferir no espaço das relações econômicas, de forma constante e aprofundada, aplicando mecanismos de autoridade, e o anseio por se conferir, às autoridades a quem couber tal intervenção, autonomia considerável ante a tradicional estrutura do poder político, são de que resulta a existência das agências reguladoras. ${ }^{51}$

Essas autarquias, portanto, entidades que integram a administração pública indireta, são de regime especial. São dotadas de peculiaridades, atribuídas a elas pelas leis que as criam, tornando-as entidades cujo regime jurídico lhes asseguram uma autonomia jurídica diferenciada de outras autarquias.

Entre elas estão, com as respectivas leis que as criaram: a Agência Nacional de Energia Elétrica (Aneel) - Lei Federal no 9.427/1996; Agência Nacional de Telecomunicações (Anatel) - Lei Federal no 9.472/1997; Agência Nacional de Petróleo (ANP) - Lei Federal no 9.478/1997; Agência Nacional de Vigilância Sanitária (Anvisa) - Lei Federal no 9.782/1999; Agência Nacional de Transportes Terrestres (ANT) e Agência Nacional de Transportes Aquaviários, ambas criadas pela Lei Federal no 10.233/2001; Agência Nacional de Saúde Suplementar - Lei Federal no 9.961/2000; e a Agência Nacional das Águas (ANA) - Lei Federal no 9.984/2000.

As peculiaridades que integram a essência das agências reguladoras são elencadas nas leis que as criam, leis estas cujo projeto é de competência do chefe do Poder Executivo, ${ }^{52}$ podendo-se encontrar autonomia administrativa, ${ }^{53}$ autonomia financeira, ${ }^{54}$ prazo por tempo fixo para o mandato de seus

50 Justen Filho, O direito das agências reguladoras independentes, op. cit., p. 344.

51 Cf. SUNDFELD, Carlos Ari. Introdução às agências reguladoras. In: SUNDFELD, Carlos Ari (Coord.). Direito administrativo econômico. São Paulo: Malheiros, 2006. p. 18.

52 "Desse modo, cabe ao Poder Legislativo determinar, no momento da criação da agência reguladora, sob as orientações dadas pelo Poder Executivo, já que o projeto de lei é de competência do Chefe do Poder Executivo (art. 61, §1ํㅡ, e, da Constituição Federal), normas gerais e abstratas (conhecidas com standards) que serão, na prática, operacionalizadas pela referida entidade autárquica de regime especial" (Lehfeld, Controles das agências reguladoras, op. cit., p. 264).

53 "A agência reguladora independente não se sujeita à revisão de seus atos por autoridade integrante da Administração direta, mas apenas perante o Poder Judiciário" (Justen Filho, O direito das agências reguladoras independentes, op. cit., p. 343).

54 "[...] visando a dotar a entidade de meios para o desempenho de suas funções." Cf. Ibid. Lucas de Souza Lehfeld ressalta que "a autonomia orçamentária e financeira dessas entidades 
administradores; ${ }^{55}$ competência fiscalizatória; ${ }^{56}$ poder para dirimir conflitos; ${ }^{57}$ e poder normativo, sendo este último o objeto de estudo do presente ensaio.

A competência regulatória das agências é que lhes confere o poder normativo. "Se sem as demais atividades um órgão ou uma entidade pode continuar a ser considerado como regulador, o mesmo não se pode dizer do poder de editar normas, sem o qual deixam de ser reguladores para serem apenas adjudicatórios" ${ }^{\prime 5}$

A natureza do poder de editar normas das agências reguladoras é regulamentar, sendo consequência da delegação de competência legislativa pela via da delegificação ou deslegalização.

Sabe-se, entretanto, que a única permissão expressa da delegação da atividade legislativa pela Constituição Federal brasileira de 1988 diz respeito às leis delegadas, sendo, portanto, em regra, vedada a delegação da ação normativa, de competência do Congresso Nacional, ao Poder Executivo, conforme artigo 25 do Ato das Disposições Constitucionais Transitórias.

Todavia, no caso da ação normativa pelas agências reguladoras, não seria compatível a vedação, isto porque "o que é vedado à Administração Pública, em regra, é o exercício de competência atribuída aos órgãos legislativos, e não do poder normativo inerente ao exercício da própria função administrativa, sem o qual não poderia dar aplicação às leis e especificar matérias como por elas demandado". ${ }^{59}$

autárquicas não transcende a gerência e operacionalização de suas receitas e bens, pois devem respeitar o regime jurídico proposto pelo Estado" (Lehfeld, Controles das agências reguladoras, op. cit., p. 252).

55 "O Presidente da República, no caso das agências federais, escolhe os dirigentes e os indica ao Senado Federal, que os sabatina e aprova (o mesmo sistema usado para os Ministros do Supremo Tribunal Federal); uma vez nomeados, eles exercem mandato, não podendo ser exonerados ad nutum; isso é o que garante efetivamente a autonomia" (Sundfeld, Introdução às agências reguladoras, op. cit., p. 25).

56 "O fundamento da atividade fiscalizatória poderá, no entanto, variar segundo a agência seja (a) reguladora de serviço público, caso em que será um dever inerente ao Poder Concedente, (b) reguladora da exploração privada de monopólio ou bem público, quando o fundamento da fiscalização é contratual, ou (c) reguladora de atividade econômica privada, em que a natureza da fiscalização é oriunda do poder de polícia exercido pela agência [...]" (Aragão, Agências reguladoras e a evolução do direito administrativo econômico, op. cit., p. 317).

57 É atribuída à agência reguladora "[...] função quase judicial, no intuito de dirimir conflitos de interesses entre empresas que prestam serviços públicos submetidos à regulação, ou entre essas e seus usuários." (Lehfeld, Controles das agências reguladoras, op. cit., p. 268).

58 Ibid., p. 316.

59 ANDRADE, Letícia Queiroz de. Poder normativo das agências reguladoras (legitimação, extensão e controle). Revista Eletrônica de Direito Administrativo Econômico, Salvador, n. 15, ago./ set./out. 2008. Disponível em:<www.direitodoestado.com.br>. Acesso em: 25 dez. 2011. 
É necessário que se perceba que a lei criadora das autarquias especiais estabelecerá limites para a ação normativa destas por meio de standards e que os regulamentos editados por elas devem ser entendidos como delegados, distinguindo-se, portanto, do regulamento autônomo e do de execução.

Andrade, que prefere chamar de regulamento de complementação o regulamento delegado, explica que

Os regulamentos de complementação não devem introduzir obrigações novas, mas, especificar as obrigações introduzidas por lei que demandem complementação técnica [...]. O exercício da competência regulamentar nos limites do espaço de liberdade conferido pela lei é condição que deve ser observada para sua compatibilidade com um sistema jurídico no qual é vedada a criação de obrigações por outro veículo que não seja a lei (art. 5o, II, da CF). ${ }^{60}$

Sobre os regulamentos executivos e autônomos, aduz Oliveira:

Os regulamentos executivos (ou de execução) destinam-se ao desenvolvimento de textos legais. A lei infraconstitucional atua como fundamento de validade e como limite desses regulamentos. Daí a afirmação de que os regulamentos executivos são editados para fiel execução da lei (art. 84, IV, da Constituição da República).

Já o regulamento autônomo é aquele cujo fundamento de validade é retirado da própria Constituição da República, não havendo, portanto, a intermediação legislativa. Nesse caso, o Executivo possui função normativa inovadora. ${ }^{61}$

É notório que isso ocorre para compatibilizar a atuação do Estado com a complexidade técnica e a especialização do momento atual da sociedade. Constitui uma forma de descentralização administrativa para realização das finalidades do Estado. Essa competência normativa que se atribui às agências reguladoras é de grande valia para o funcionamento e a organização da administração pública, não representando "propriamente inovação da ordem jurídica, pois não são competentes para legislar. Na realidade, estabelecem

60 Ibid.

61 Oliveira, Constitucionalização do direito administrativo, op. cit., p. 56. 
normas (regras) de cunho operacional, a fim de suprir, com eficiência, as metas e objetivos a elas previamente estabelecidos" ${ }^{62}$

\subsection{A constitucionalidade do poder normativo, o redimensionamento do princípio da legalidade e a releitura do princípio da tripartição de poderes}

De antemão, é de bom alvitre ressaltar que a defesa da constitucionalidade do poder normativo das agências reguladoras não deve soar como competência dessas autarquias para a produção de regulamentos autônomos, pois todo o poder normativo a elas atribuído deve estar nos moldes e limites das determinações legais da lei que as criaram. ${ }^{63}$

O que fará as agências reguladoras, pois, quando do exercício do seu poder normativo, é operacionalizar os standards determinados pelo Poder Legislativo quando criarem essas autarquias. Por standards pode-se entender as normas gerais e abstratas, cuja competência para operacionalização prática será das agências reguladoras, por determinação das leis que as instituírem.

Conforme Aragão,

Podemos ver, com efeito, que apesar da maior ou menor magnitude de poder normativo legalmente outorgado nas suas esferas de atuação, todas as agências reguladoras - umas mais e outras menos possuem competências normativas calcadas em Standards, ou seja, em palavras dotadas de baixa densidade normativa, às vezes meramente habilitadoras, devendo exercer estas competências na busca da realização das finalidades públicas - também genéricas - fixadas nas suas respectivas leis. ${ }^{64}$

62 Lehfeld, Controles das agências reguladoras, op. cit., p. 264.

63 Neste sentido, Carlos Ari Sundfeld, ao afirmar, sobre o poder normativo das agências reguladoras: "Quando reconheço ser constitucionalmente viável que elas desfrutem de um tal poder, de modo algum estou sugerindo que elas produzam 'regulamentos autônomos' ou coisa parecida, pois todas as suas competências devem ter base legal - mesmo porque só a lei pode criá-las, conferindo-lhes (ou não) poderes normativos." (Sundfeld, Introdução às agências reguladoras, op. cit., p. 27).

64 Aragão, Agências reguladoras e a evolução do direito administrativo econômico, op. cit., p. 408. 
Ou seja, "as leis instituidoras das agências reguladoras integram, destarte, a categoria das leis-quadro (lois-cadre) ou standartizadas, próprias das matérias de particular complexidade técnica e dos setores suscetíveis a constantes mudanças econômicas e tecnológicas". 65 "A constitucionalidade da lei atributiva depende de o legislador haver estabelecido Standards suficientes, pois do contrário haveria delegação pura e simples de função legislativa." 66

Todo esse repasse de poder normativo para as agências reguladoras faz sentido no contexto da complexidade e tecnicidade das relações sociais e econômicas, já que o Estado se incumbiu de promover o bem comum de forma eficiente, atendendo aos princípios democráticos e aos preceitos da justiça social.

Conforme Ferreira Filho, a recusa do poder normativo ao Poder Executivo não impede uma crise democrática. Se outorgar esse poder ao Executivo, pode acarretar arbítrio, ameaçando a democracia, e recusar poderá destruí-la. A recusa de atribuição do poder normativo a quem se apresenta em condições de exercitá-lo, com certo grau de eficiência, pode levar o governo à impotência e a democracia ao desastre. ${ }^{67}$

Nessa perspectiva, desborda, do pensamento harmônico com os princípios democráticos que estruturam a ideia de bem comum, o pensar que quer se manter, por laços inseparáveis, ligado aos formalismos arraigados do princípio da legalidade e da tripartição de poderes. Logo, a releitura desses princípios se mostra imprescindível para a consecução do próprio Estado constitucional democrático de direito.

Como assevera Aragão,

Podemos afirmar que as competências complexas das quais as agências reguladoras independentes são dotadas fortaleçam o Estado de Direito, vez que, ao retirar do emaranhado das lutas políticas a regulação de importantes atividades sociais e econômicas, atenuando a concentração de poderes na Administração Pública central, alcançam, com melhor proveito, o escopo maior - não meramente formal - da separação de poderes, qual seja, o de garantir eficazmente a segurança jurídica, a proteção da coletividade e dos indivíduos empreendedores

65 Ibid.

66 Sundfeld, Introdução às agências reguladoras, op. cit., p. 27.

67 FERREIRA FILHO, Manoel Gonçalves. Do processo legislativo. 6. ed. São Paulo: Saraiva, 2007. p. 16. 
de tais atividades ou por elas atingidos, mantendo-se sempre a possibilidade de interferência do Legislador, seja para alterando regime jurídico da agência reguladora, ou mesmo para extingui-la. ${ }^{68}$

Lehfeld, por sua vez, explica que o objetivo da separação dos poderes deve ser analisado na perspectiva de dinâmica do poder do Estado, não deixando a teoria de limitar a ação estatal ante os direitos e garantias fundamentais da sociedade, nem abandonando o "controle recíproco entre os poderes por causa do princípio do checks and balances".

Todavia, continua o autor, de outra banda, impõe uma interpretação mais flexível, em razão da complexificação, cada vez mais presente, das questões submetidas ao domínio da atuação do Estado, que vai se compor de organismos técnicos, que estejam próximos à problemática, tais como as agências reguladoras. ${ }^{69}$

Demais disso, a visão do princípio da legalidade nos moldes do Estado liberal queda-se também insustentável perante o cenário da sociedade e economia atual. "Frente à crise da noção liberal de legalidade administrativa, necessário se faz identificar uma nova concepção do princípio da legalidade administrativa, mais consentânea com a realidade moderna." ${ }^{\prime 70}$

Por oportuno, ressaltem-se as lições de Clève:

Está agonizando um conceito de lei, um tipo de parlamento e uma determinada concepção do direito. $\mathrm{O}$ parlamento monopolizador da atividade legiferante do Estado sofreu abalos. Deve continuar legislando, é certo. Porém, a função legislativa será, no Estado contemporâneo, dividida com o executivo. O parlamento não deve deixar de reforçar o seu poder de controle sobre os atos, inclusive normativos, do Executivo. ${ }^{71}$

O que se percebe com isso é a necessidade de adaptação dos princípios da legalidade e da tripartição dos poderes à atualidade dos reclamos, não só políticos, mas também sociais e econômicos. Isso porque a tradicional produção normativa pelo Poder Legislativo mostra-se tecnicamente despreparada

\footnotetext{
Aragão, Agências reguladoras e a evolução do direito administrativo econômico, op. cit., p. 275-276.

Lehfeld, Controles das agências reguladoras, op. cit., p. 166.

Oliveira, Constitucionalização do direito administrativo, op. cit., p. 42.

${ }^{71}$ Clève, Atividade legislativa do Poder Executivo, op. cit., p. 57.
} 
para regulamentar determinadas matérias, além de não acompanhar a dinamicidade das relações sociais da contemporânea sociedade.

Comparato, referindo-se aos princípios da legalidade e da tripartição de poderes, preleciona que:

O mundo contemporâneo - a partir do final da guerra europeia de 1914-1918 e, sobretudo, desde a grande crise de 1929 - subverteu ambos esses princípios: a lei deixou de ser a norma geral, igualmente aplicável a todos os que vivem debaixo de um mesmo Estado, e o Poder Executivo tornou-se autêntico legislador. ${ }^{72}$

Há uma necessidade de se implantar mecanismos que sirvam de apoio para a adequação da atuação do Estado no tocante à complexidade social, o que exige a flexibilização dos referidos princípios. Daí a importância da lição de Justen Filho quando traz à tona que:

A dimensão quantitativa e a complexidade qualitativa são problemas que conduzem a tornar vagarosa a regulação estatal sobre certas matérias. A criação de agências permite superar essas dificuldades, eis que se reduz o número de participantes no processo decisório final, amplia-se a especialização do órgão e se reduz a demora na geração de atos estatais. $^{73}$

Ferreira Filho, a propósito da crise da lei e da falência dos Parlamentos, relata:

É notório que os Parlamentos não dão conta das "necessidades" legislativas dos Estados contemporâneos; não conseguem, a tempo e a hora, gerar as leis que os governos reclamam, que os grupos de pressão solicitam. As normas que tradicionalmente pautam o seu trabalho dão - é certo - ensejo a delongas, oportunidade a manobras e retardamentos. Com isso, os projetos se acumulam e atrasam...

Nem estão os parlamentos, por sua própria organização, em condições de desempenhar, lentamente mas a contento, a função legislativa.

72 COMPARATO, Fábio Konder. A organização constitucional da função planejadora. Revista Trimestral de Direito Público, São Paulo, p. 14, 29 ago. 1994.

73 Justen Filho, O direito das agências reguladoras independentes, op. cit., p. 361. 
O modo de escolha de seus membros torna-os pouco frequentados pela ponderação e pela cultura, mas extremamente sensíveis à demagogia e à advocacia em causa própria. Os interesses não têm dificuldade em encontrar porta-vozes eloquentes, o bem comum nem sempre os acha. Por outro lado, o seu modo de trabalhar também é inadequado às decisões que deve tomar. Como, por exemplo, estabelecer um planejamento por meio de um debate parlamentar $?^{74}$

Percebe-se, pois, uma imperiosa descentralização da produção normativa, o que acarreta a perda do monopólio de legislar pelo Poder Legislativo, em função da necessidade de o Estado cumprir de forma eficiente as tarefas assumidas e das exigências de normas técnicas e específicas com produção dinâmica. Isso requer maior flexibilização no processo legislativo, o que se tornou incompatível com os métodos de produção legislativa pregados pelo Estado Liberal.

\subsection{O poder normativo das agências reguladoras no contexto do neoconstitucionalismo}

Com o neoconstitucionalismo, a Constituição deixa de ser mero documento político para se tornar a mais importante norma de um Estado, dela irradiando a força capaz de vincular todo o ordenamento jurídico à vontade nela contida. É a saída de um Estado legislativo de direito, nos moldes do liberalismo clássico, com centralidade na lei, para um Estado constitucional de direito com a centralidade jurídica voltada para a Constituição.

A partir de então, a Constituição passa a ter força normativa. ${ }^{75}$ Em razão disso, passa ela a exigir que seja cumprida a sua vontade, ou seja, os direitos, garantias e valores fundamentais da Constituição necessitam ser realizados pelo Estado.

A produção normativa, portanto, precisa ser compatível com essa nova forma de visualizar a Constituição: a máxima efetividade das normas constitucionais como reflexo da concretização de direitos fundamentais.

74 Manoel Gonçalves Ferreira Filho, Do processo legislativo, op. cit., p. 14-15.

75 Sobre a força normativa da constituição, é relevante observar: HESSE, Konrad. A força normativa da Constituição. Tradução de Gilmar Ferreira Mendes. Porto Alegre: Sergio Antonio Fabris, 1991. 


\section{Segundo Hesse,}

Embora a Constituição não possa, por si só, realizar nada, ela pode impor tarefas. A Constituição transforma-se em força ativa se essas tarefas forem efetivamente realizadas, se existir a disposição de orientar a própria conduta segundo a ordem nela estabelecida, se, a despeito de todos os questionamentos e reservas provenientes dos juízos de conveniência, se puder identificar a vontade de concretizar essa ordem. ${ }^{76}$

Por consequência, o poder normativo das agências reguladoras tem que ter compasso harmônico com a vontade constitucional. Caminham as agências para a concretização do bem comum, atuando para assegurar direitos fundamentais e protegendo a sociedade por meio de normas, cujo fim é atender o equilíbrio econômico, a justiça social e a dignidade humana, compatível são elas, pois, com a Constituição e com o Estado democrático. Até porque sua forma de atuação produtiva de normas está limitada aos standards contidos na lei que as criou.

Importante observação, sobre o poder normativo das agências, faz Sundfeld:

Será verdade, como temem alguns, que a agência reguladora é necessariamente uma usurpadora da função legislativa? Não. Nos novos tempos, o Poder Legislativo faz o que sempre fez: edita leis, frequentemente com alto grau de abstração e generalidade. Só que, segundo os novos padrões da sociedade, agora essas normas não bastam, sendo preciso normas mais diretas para tratar das especificidades, realizar o planejamento dos setores, viabilizar a intervenção do Estado em garantia do cumprimento ou realização daqueles valores: proteção do meio ambiente e do consumidor, busca do desenvolvimento nacional, expansão das telecomunicações nacionais, controle sobre o poder econômico - enfim, todos esses que hoje consideramos fundamentais e cuja persecução exigimos do Estado. ${ }^{77}$

\footnotetext{
76 Ibid., p. 19.

77 Sundfeld, Introdução às agências reguladoras, op. cit., p. 27.
} 
As agências reguladoras, dessa forma, não invadem o espaço reservado constitucionalmente para o Poder Legislativo, mas atuam, é clarividente, na busca da vontade da Constituição.

O Estado assumiu o compromisso de concretizar direitos, de estabelecer o equilíbrio da economia, de efetivar o bem comum, de realizar a democracia e fazer valer a justiça social. É esse o sentido do poder normativo das agências reguladoras, o que não destoa dos mandamentos constitucionais, mas sim caminha lado a lado com eles.

O Estado não pode parar no tempo e esperar por soluções pautadas em conceitos e modelos ultrapassados que obstem a concretização da democracia. O Estado precisa ser atual, atendendo às necessidades atuais da sociedade, afinal de contas, é para ela que ele existe. No dizer de García-Pelayo, ao explanar as funções do Estado como objeto da Constituição,

El Estado solo tiene existencia en cuanto que es actual, y esta actualidad la alcanza únicamente en cuanto actúa, es dicir, en cuanto que de modo permanente e ininterrumpido realiza una serie de actos. En el momento en que tales actos dejan de tener lugar cesa de ser una realidad presente para convertirse en un pasado histórico. La unidad del Estado no es, pues, una unidad estática, sino una unidad que existe en cuanto que constantemente deviene; su ser, por consiguinte, no consiste en la permanencia parménica, sino en el devenir heraclitiano; sus constantes, su status, no son más que momentos de una renovación permanente. ${ }^{78}$

Ademais, conforme anuncia Comparato,

a organização de Poderes do Constitucionalismo clássico, fundada na supremacia da lei e do órgão legislativo, apresenta um defeito irremediável, qual seja, a ausência de um órgão de impulsionamento da ação estatal. Rompendo com o esquema constitucional consagrado, o Poder Executivo assumiu, em todos os países, essa função natural de liderança, tornando-se, de fato, o principal Poder. ${ }^{79}$

78 García-Pelayo, Derecho constitucional comparado, op. cit., p. 103.

79 Comparato, A organização constitucional da função planejadora, op. cit., p. 25. Faz-se necessário observar que, embora este autor se refira ao Poder Executivo como principal Poder, com o neoconstitucionalismo, em razão da grande importância dada à Constituição, o protagonismo dos Poderes voltou-se para o Judiciário, por ser ele o Poder guardião da Carta Magna. 
Ora, para atender ao que manda a Constituição, o Poder legislativo, por si só, já não é capaz, seja pela sua insuficiência técnica, seja pela lentidão no processo legislativo, seja pela defesa de interesses próprios dos parlamentares. É imprescindível, dessa forma, a criação de meios alternativos que atendam aos interesses sociais e realizem os direitos fundamentais de maneira ágil e técnica, o que reflete a própria eficiência da administração pública. Eis a necessidade do poder normativo das agências reguladoras. ${ }^{80}$

\section{Considerações finais}

Como se pode notar, a passagem do Estado de liberal para social fez com que ele, Estado, assumisse o papel intervencionista, tanto no âmbito econômico como na esfera das relações sociais, o que era inadmissível no liberalismo burguês das liberdades individuais e da livre-iniciativa.

Entretanto, o tempo mostrou que o Estado não poderia por si só atender a todas as necessidades sociais, já que faltavam recursos financeiros para isso. Foi isso, pois, que levou à ascensão do Estado neoliberal, no qual o Estado permite a livre-iniciativa, mas regula a atividade econômica como forma de garantir o bem comum.

O poder normativo das agências reguladoras é, desta forma, conditio sine qua non para a atividade reguladora do Estado. É em razão da competência reguladora que essas autarquias podem editar normas. Normas essas fundamentais para a realização da democracia, da justiça social, do equilíbrio econômico, da vontade constitucional e do próprio estado constitucional democrático de direito, já que exercem a regulação de um determinado setor econômico com fim de atingir o bem-estar social.

Nessa perspectiva, a análise da insuficiência do Poder Legislativo se faz imprescindível, o que requer um redimensionamento do princípio da

80 Marçal Justen Filho pronuncia que "a atribuição de competências administrativa a entidades dotadas de autonomia, que concentrem conhecimento técnico-científico e a habilidades especiais, poderá conduzir à substituição de um modelo político-administrativo perverso até agora vigente. As decisões administrativas têm sido fortemente influenciadas pela conveniência subjetiva do exercente do cargo público, inclusive se prestando a operações eticamente reprováveis destinadas a conquistar e a manter o clientelismo político. A criação da agência poderá evitar que o exercício de relevantes competências administrativas seja abrangido no campo de negociação política" (Justen Filho, O direito das agências reguladoras independentes, op. cit., p. 592). 
legalidade e uma releitura da teoria da tripartição dos poderes. Foi o que se pretendeu, em linhas anteriormente descritas, quando se apontou a falta de conhecimento técnico dos parlamentares, a inércia do Legislativo para a normatização de algumas matérias e a superposição de interesses pessoais de integrantes da Casa Legislativa sobre os interesses da sociedade.

Essa incompatibilidade da produção normativa exclusivamente pelo Legislativo com as exigências cada vez mais técnicas, complexas e dinâmicas da sociedade contemporânea exige uma flexibilização desses princípios. $\mathrm{O}$ radicalismo do liberalismo burguês, portanto, se mostra anacrônico. Deve-se sim aplicar tais ideias, mas em consonância com a vontade social e constitucional estabelecidas no espaço e no tempo.

Ressalte-se que a partir do neoconstitucionalismo a Constituição tornouse o centro do ordenamento jurídico, passando a ter força normativa e a determinar seu cumprimento. Os direitos fundamentais, por sua vez, nessa ótica, se tornaram a pedra de toque do sistema constitucional, é o que se diz da dignidade da pessoa humana, por exemplo. Nesse ângulo, a concretização desses direitos implica realização dos desejos constitucionais.

Cabe ao Estado contemporâneo, portanto, encontrar mecanismos que façam valer esses mandamentos. A descentralização da produção normativa se apresenta como um desses mecanismos. Dessa forma, por óbvio, o poder normativo das agências reguladoras caminha em harmonia com esses ideais, pois visa suprir a insuficiência do Poder Legislativo na produção de normas que assegurem os direitos e anseios da sociedade e da Constituição.

Por todo o exposto é que se pretende firmar que o poder normativo das agências reguladoras é constitucional na ótica do redimensionamento do princípio da legalidade.

\section{Referências}

ANDRADE, Letícia Queiroz de. Poder normativo das agências reguladoras (legitimação, extensão e controle). Revista Eletrônica de Direito Administrativo Econômico, Salvador, n. 15, ago./set./out. 2008. Disponível em: <www. direitodoestado.com.br>. Acesso em: 25 dez. 2011.

ARAGÃO, Alexandre Santos de. Agências reguladoras e a evolução do direito administrativo econômico. 2. ed. Rio de Janeiro: Forense, 2006. 
. Legalidade e regulamentos administrativos no direito contemporâneo. Uma análise doutrinária e jurisprudencial. Revista de Direito Constitucional e Internacional, São Paulo, n. 41, p. 284-310, out./dez. 2002.

BARROSO, Luis Roberto. Constituição e ordem econômica e agências reguladoras. Revista Eletrônica de Direito Administrativo Econômico, Salvador, n. 1, fev. 2005. Disponível em: <www.direitodoestado.com.br>. Acesso em: 25 dez. 2011.

- Neoconstitucionalismo e constitucionalização do direito (o triunfo tardio do direito constitucional no Brasil). Revista Eletrônica sobre a Reforma do Estado (Rere), Salvador, n. 9, mar./abr./maio 2007. Disponível em: <HTTP:// direitodoestado.com.br/rere.asp>. Acesso em: 22 set. 2011.

BOBBIO, Norberto. Direito e Estado no pensamento de Emanuel Kant. 2. ed. Tradução de Alfredo Fait. São Paulo: Mandarim, 2000.

BONAVIDES, Paulo. Curso de direito constitucional. 23. ed. São Paulo: Malheiros, 2008.

CARVALHO FILHO, José dos Santos. Estado mínimo $\times$ Estado máximo: o dilema. Revista Eletrônica sobre a Reforma do Estado (Rere), Salvador, n. 12, dez./ jan./fev. 2008. Disponível em: <HTTP://direitodoestado.com.br>. Acesso em: 20 dez. 2011.

COMPARATO, Fábio Konder. A organização constitucional da função planejadora. Revista Trimestral de Direito Público, São Paulo, n. 8, p. 12-23, 29 ago. 1994.

CLÈVE, Clèmerson Merlin. Atividade legislativa do Poder Executivo. 2. ed. São Paulo: Revista dos Tribunais, 2000.

DALLARI, Dalmo de Abreu. Elementos de teoria geral do estado. 24. ed. São Paulo: Saraiva, 2003.

ENTERRÍA, Eduardo García; FERNÁNDEZ, Tomás-Ramón. Curso de derecho administrativo. Madri: Civitas, 2002. v. I.

FERREIRA FILHO, Manoel Gonçalves. Do processo legislativo. 6. ed. São Paulo: Saraiva, 2007.

GARCÍA-PELAYO, Manuel. Derecho constitucional comparado. 4. ed. Madri: Revista de Ocidente, S.A., 1957. 
HESSE, Konrad. A força normativa da Constituição. Tradução de Gilmar Ferreira Mendes. Porto Alegre: Sergio Antonio Fabris, 1991.

JUSTEN FILHO, MARÇAL. O direito das agências reguladoras independentes. São Paulo: Dialéctica, 2002.

KRELL. Andreas J. Leis de normas gerais, regulamentação do Poder Executivo e cooperação intergovenamental em tempos de reforma federativa. Belo Horizonte: Fórum, 2008.

LEHFELD, Lucas de Souza. Controles das agências reguladoras. São Paulo: Atlas, 2008.

MONCADA, Luís S. Cabral de. Ensaio sobre a lei. Coimbra: Coimbra, 2002.

OLIVEIRA, Rafael Carvalho Rezende. Constitucionalização do direito administrativo. 2. ed. Rio de Janeiro: Lumen Juris, 2010.

PAULA, Daniel Giotti de. Ainda existe separação de poderes? A invasão da política pelo direito no contexto do ativismo judicial e da judicialização da política. In: PAULA, Daniel Giotti de; FELLET, André Luiz Fernandes; NOVELINO, Marcelo (Org.). As novas faces do ativismo judicial. Salvador: Juspodivm, 2011. p. 271-312.

SAMPAIO JÚNIOR, José Herval. Ativismo judicial: autoritarismo ou cumprimento dos deveres constitucionais? In: DE PAULA, Daniel Giotti; FELLET, André Luiz Fernandes; NOVELINO, Marcelo (Org.). As novas faces do ativismo judicial. Salvador: Juspodivm, 2011. p. 403-429.

SARMENTO, Daniel. O neoconstitucionalismo no Brasil: riscos e possibilidades. In: DE PAULA, Daniel Giotti; FELLET, André Luiz Fernandes; NOVELINO, Marcelo (Org.). As novas faces do ativismo judicial. Salvador: Juspodivm, 2011. p. 73-113.

SUNDFELD, Carlos Ari (Coord.). Direito administrativo econômico. São Paulo: Malheiros, 2006. 